Portland State University

PDXScholar

2014

\title{
Sense of Place and Stakeholder Involvement in Rural Environmental Management
}

Jessica Lynn Beutler

Portland State University

Follow this and additional works at: https://pdxscholar.library.pdx.edu/honorstheses

\section{Let us know how access to this document benefits you.}

\section{Recommended Citation}

Beutler, Jessica Lynn, "Sense of Place and Stakeholder Involvement in Rural Environmental Management" (2014). University Honors Theses. Paper 47.

https://doi.org/10.15760/honors.75

This Thesis is brought to you for free and open access. It has been accepted for inclusion in University Honors Theses by an authorized administrator of PDXScholar. Please contact us if we can make this document more accessible: pdxscholar@pdx.edu. 
Sense of Place and Stakeholder Involvement in Rural Environmental Management

by

Jessica Lynn Beutler

An undergraduate honors thesis submitted in partial fulfillment of the

requirements for the degree of

Bachelor of Science

in

University Honors

and

Environmental Studies

Thesis Adviser

Dr. Rebecca McLain

Portland State University 


\section{Abstract}

There is a growing need for involvement of local communities in environmental management in order to develop dynamic and holistic management strategies. Communities have direct impact on the ecosystems they live in; therefore, it is vital to understand the environmental values and knowledge of environmental threats held by those communities. Integrating the community's knowledge into local environmental management can help engage instead of alienate them. The relationship between rural communities and their local environment in Puget Island, WA was investigated by conducting interviews with residents, examining their values and understanding of environmental issues. Additionally, this research investigates how sense of place can change with the shifting social, economic, and environmental conditions on the island. Finally, this research looks at whether environmental management of the island aligns with the views of residents, shows a need for stronger communitybased environmental management.

Interviews with residents revealed a division between established and new residents as a source of social tension on the Island. Sense of place was strong with both groups; however, the values held by residents are changing with an increase in new residents. Newer residents were more aware of environmental issues but not as likely as established residents to be actively involved in the community. Further research showed that a knowledge gap exists between residents and environmental management agencies in how and why issues are being managed. It is recommended that residents form a representative organization to communicate with these agencies, and promote the environmental protection of the Island. 


\section{Acknowledgements}

I would like to express my gratitude to my adviser, Dr. Rebecca McLain, for guiding me through my project and being a tremendous source of support. In addition to her support in this thesis, Dr. McLain has provided me with invaluable research experience and education in cultural value mapping.

I would also like to thank Dr. Ann Marie Fallon and the Portland State University Honors College for supporting me throughout these past three years at Portland State University. Dr. Fallon and the Honors College have broadened my education through the Grand Canyon Semester and a variety of other academic opportunities. I would not have had the diverse educational experience that I have had without the Honors College.

Professor Ben Anderson-Nathe helped guide me through the Human Subjects Research Review Committee process for research approval. Without his support, I would have completely lost and would not have been able to complete my research in a timely matter.

Ultimately, my research would not have been possible without the help and encouragement from my father and step-mother, Mike Beutler and Liz Norris. Together, they communicated with Puget Island residents and set up the majority of interviews. Their connection to the Island and its residents provided unique insight into the community.

Finally, I would like to thank all of the Puget Island residents that were willing to take the time to share their stories and opinions with me and inviting me into their homes. 


\section{Table of Contents}

Introduction $\quad \mathbf{5}$

1 Aim 5

2 Hypothesis 5

3 Geographical and Ecological Context 6

4 Social and Historical Context $\quad 7$

5 Environmental and Land Management 8

6 Reason for Location Selection 10

Literature Review

7 Community-Based Environmental Management 11

$\begin{array}{lll}7.1 & \text { Stakeholder Involvement } & 12\end{array}$

8 Sense of Place 13

8.1 Sense of Place and the Environment 14

8.2 Sense of Place in Environmental Assessment 14

8.3 Measuring Human Values and Sense of Place 15

Methodology 16

9 Approach 16

$\begin{array}{llr}9.1 & \text { Recruitment } & 17\end{array}$

$\begin{array}{lll}9.2 & \text { Semi-Structured Interviews } & 17\end{array}$

10 Data Collection 18

$\begin{array}{llr}10.1 & \text { Timescale } & 18\end{array}$

\begin{tabular}{ll}
10.2 & Interviewee Distribution \\
\hline
\end{tabular}

11 Analysis $\quad 19$

12 Limitations $\quad 20$

Findings and Analysis $\quad \mathbf{2 1}$

13 Relationship to the Island 21

14 Resident Values $\quad 22$

15 Environmental Awareness of Residents 22

16 Environmental Protection on Puget Island 23

17 Established Versus Newer Residents 24

17.1 Comparison of Values 26

17.2 Comparison of Environmental Awareness 26

18 Resident Recommendations 26

19 Public Involvement in Environmental Management 27

19.1 Columbian White-Tailed Deer Management 27

$\begin{array}{lll}19.2 & \text { Beach Erosion } & 31\end{array}$

$\begin{array}{ll}\text { Discussion } & 33\end{array}$

$\begin{array}{ll}\text { Conclusion } & 36\end{array}$

$\begin{array}{ll}\text { Bibliography } & 37\end{array}$

Appendix A: Interview Questions Outline 39

Appendix B: Survey Matrices 40 


\section{List of Tables and Figures}

Table 1 - Frequency of discussion of values in interviews $\quad 21$

Table 2 - Frequency of discussion of environmental issues or concerns in interviews 22

Fig. 1 - Map of Puget Island, WA and nearby Cathlamet, WA 6

Fig. 2 - Map of Puget Island Land Use $\quad 9$

Fig. 3 - Map of Interviewee Residence Distribution $\quad 18$

Fig. 4 - Range of Columbian White-Tailed Deer in the Columbia River estuary $\quad 27$

Fig. 5 - Capture sites of Columbian White-tailed Deer 28 


\section{Introduction}

\section{Aim}

While environmental management is often portrayed as a top-down system regulated by government entities, communities have direct impacts on and relationships with the ecosystems they live in. Therefore, it is vital to understand the environmental values held by those communities and their knowledge of environmental threats. Integrating the community's knowledge into local environmental management can, presumably, help create a more holistic environmental management strategy that engages instead of alienating the local communities.

This research has three goals. First, to better understand the sense of place held by residents of Puget Island and their relationship to the environment of the Island. Second, to illustrate how sense of place can change with changing conditions in the community. Finally, the primary aim of this research is to look at whether or not environmental management of the island aligns with the opinions of residents and whether or not there is a need for stronger community-based environmental management.

\section{Hypothesis}

I examine two hypotheses in this study: firstly, residents have a strong sense of place and understanding of environmental concerns but changes to the community are weakening this sense of place; secondly, there is a significant difference between residents' views and understandings of environmental issues and those of environmental managers. 


\section{Geographical and Ecological Context}

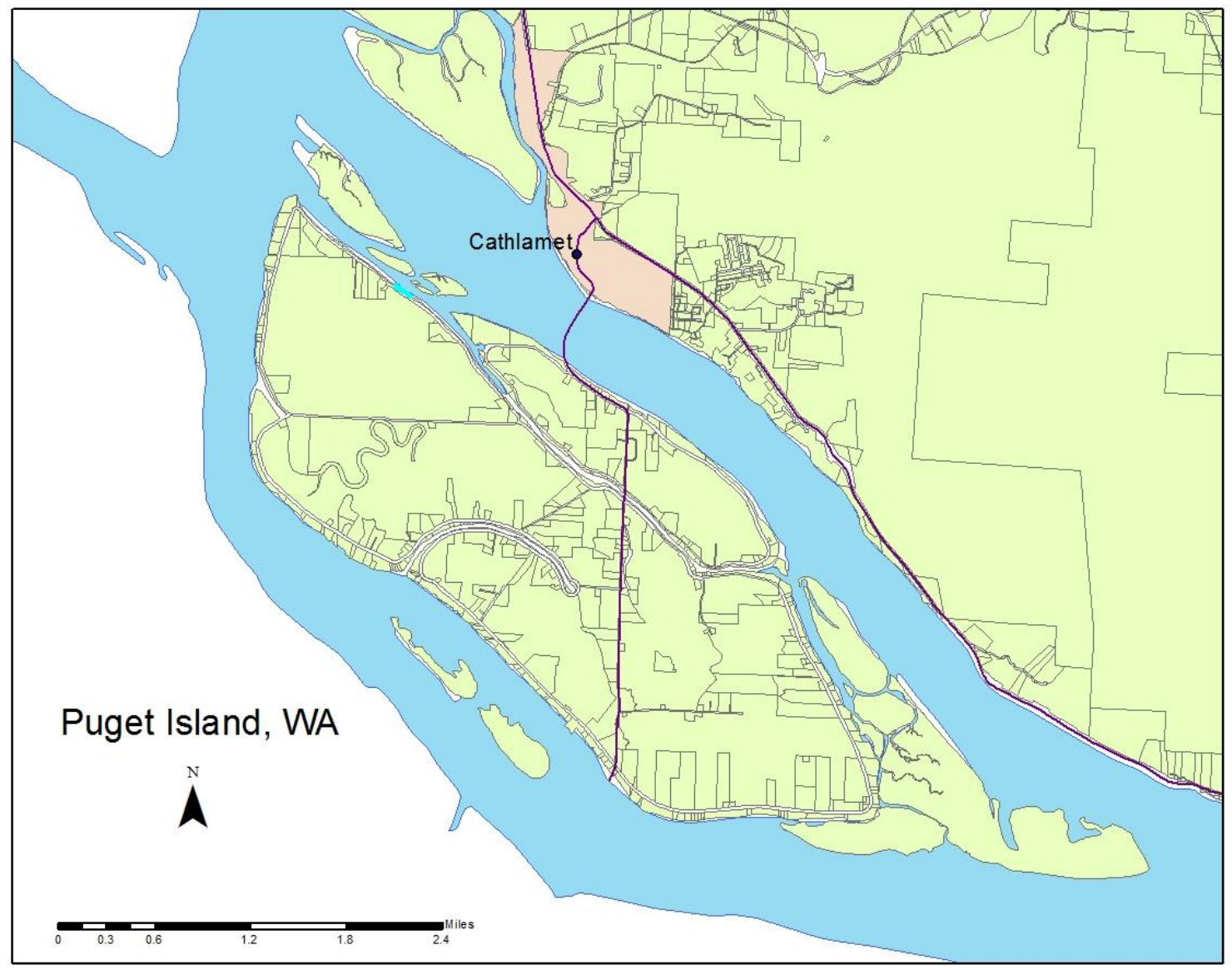

Figure 1 - Map of Puget Island, WA and nearby Cathlamet, WA. Map by Jessica Beutler; data courtesy of Washington State Department of Ecology GIS Technical Services and Washington State Department of Transportation Office of Information Technology.

Puget Island is a 4,785 acre (7.5 sq mi) island located on the lower Columbia River between Oregon and Washington under Washington jurisdiction. The island sits between river miles 38 and 45 approximately halfway between Longview, WA and Astoria, OR. It is accessible from the north by the Julia Butler-Hansen Bridge connecting the Island to Cathlamet, WA by SR 409 and to the south by a county-run commuter ferry to Westport, OR.

Geographically, Puget Island consists of two islands, Little Island and Puget Island, which are dissected with numerous sloughs and dikes. The two islands are a pair in a chain of islands, most of which are uninhabited and some only distinctive during low river levels. For the purpose of this paper and as recognized by the government 
agencies, Little Island and Puget Island will be collectively referred to as Puget Island. Before the construction of dikes permanently altered the floodplain, Puget Island was crisscrossed by numerous channels created by the Columbia River at different heights of flooding (Board of Wahkiakum County Commissioners [BWCC], 2008).

Undeveloped areas on the island consist of rocky and sandy beaches and Sitka spruce swampland. On the western end of the island, there is the Robert W. Little Nature Preserve, a Sitka spruce swamp owned by the Nature Conservancy. Funds for the purchase of the property were donated to the Nature Conservancy in 1991 by the family of the late resident Robert W. Little. The land serves as important habitat for the endangered Columbian White-Tailed Deer. The limited habitat in the area is confined mostly to the Julia Butler-Hansen Wildlife Refuge on the Washington side of the Columbia River, various uninhabited islands, and undeveloped sections of Puget Island. (Nature Conservancy, 2014)

Along the entirety of the Columbia River estuary from Bonneville Dam to the mouth of the river, large tracts of floodplain, marshlands, and swamp habitats have been significantly disconnected or altered by the development of the land for agriculture, industry, and residential development. It is estimated that 77 percent of historically forested and tidal swamp area, and 43 percent of historical marshland have been lost since 1870 in the lower estuary. Puget Island has not been immune to the impacts from human development. (US Fish and Wildlife Service [USFWS], 2010)

\section{Social and Historical Context}

Puget Island is an unincorporated community of 831 residents, which as of 2010, consisted largely of an older white community (U.S. Census Bureau). While the island has traditionally been dominated by agricultural purposes, land use is becoming increasingly residential (Martin, 1997). Few businesses operate on Puget Island. Residents typically use the bridge to Cathlamet, WA, a town of 532 residents (U.S. Census Bureau), for access to groceries and other services. The Norse Hall, fire station, and several churches provide space for potential social 
events and centers for public services on the island. However, with the exception of the Two Island's Farmer's Market, most social and cultural activity for the community takes place in Cathlamet.

The history of Puget Island and the larger culture of Cathlamet and Wahkiakum County since white settlement in the 1800s has been centered around economic development in three areas: logging, fishing, and farming (Martin, 1997). The development of the area can be linked to two major factors: development of flood control and immigrant communities. Scandinavian immigrants comprised the majority of settlers in the region. The area provided them with an economic setting comparable to their homelands (Martin, 1997). As such, the culture of the region was heavily influenced by its Scandinavian roots that are still visible today. Additionally, the construction of dams upstream on the Columbia and dikes on Puget Island allowed for permanent settlement on the island without disturbances from annual flooding (Martin, 1997).

Early settlers valued the landscape for the economic opportunity it offered. Oftentimes, due to the abundance of natural resources, early settlers of the region took up pluralist lifestyles by owning property for dairy farming, fishing during the summer, and logging during the rest of the year (Martin, 1997). However, with environmental regulations, changing economic conditions, and development of pasture land, the three economic pillars in Wahkiakum County suffered a significant blow. To this day, despite this economic shift, these three industries remain a critical part of the culture as seen through local art, festivals, and other forms of cultural expression.

In recent decades, Puget Island, as well as the surrounding county, has undergone a significant cultural and economic shift away from a rural community based around natural resource extraction to a bedroom community for the region's urban areas (Martin, 1997). Today, Puget Island is one of the two fastest growing areas of Wahkiakum County with a projected population of 1,515 by 2020 (BWCC, 2008). Subsequently, the social fabric of the community has become gradually less dominated by descendants of the original immigrant families (Martin, 1997). 


\section{Environmental and Land Management}

While many state, federal, and non-profit entities have jurisdiction and/or interests on Puget Island, four key management agencies play a role in the land and environmental management of the island: Wahkiakum County, US Fish and Wildlife Service [USFWS], Washington Department of Ecology, and the Army Corps of Engineers. Additionally, the Nature Conservancy owns a plot of land on the northwestern side of the island. However, the Nature Conservancy does not appear to take an active role in the environmental management of the island. Overall, Puget Island is mostly privately owned property.

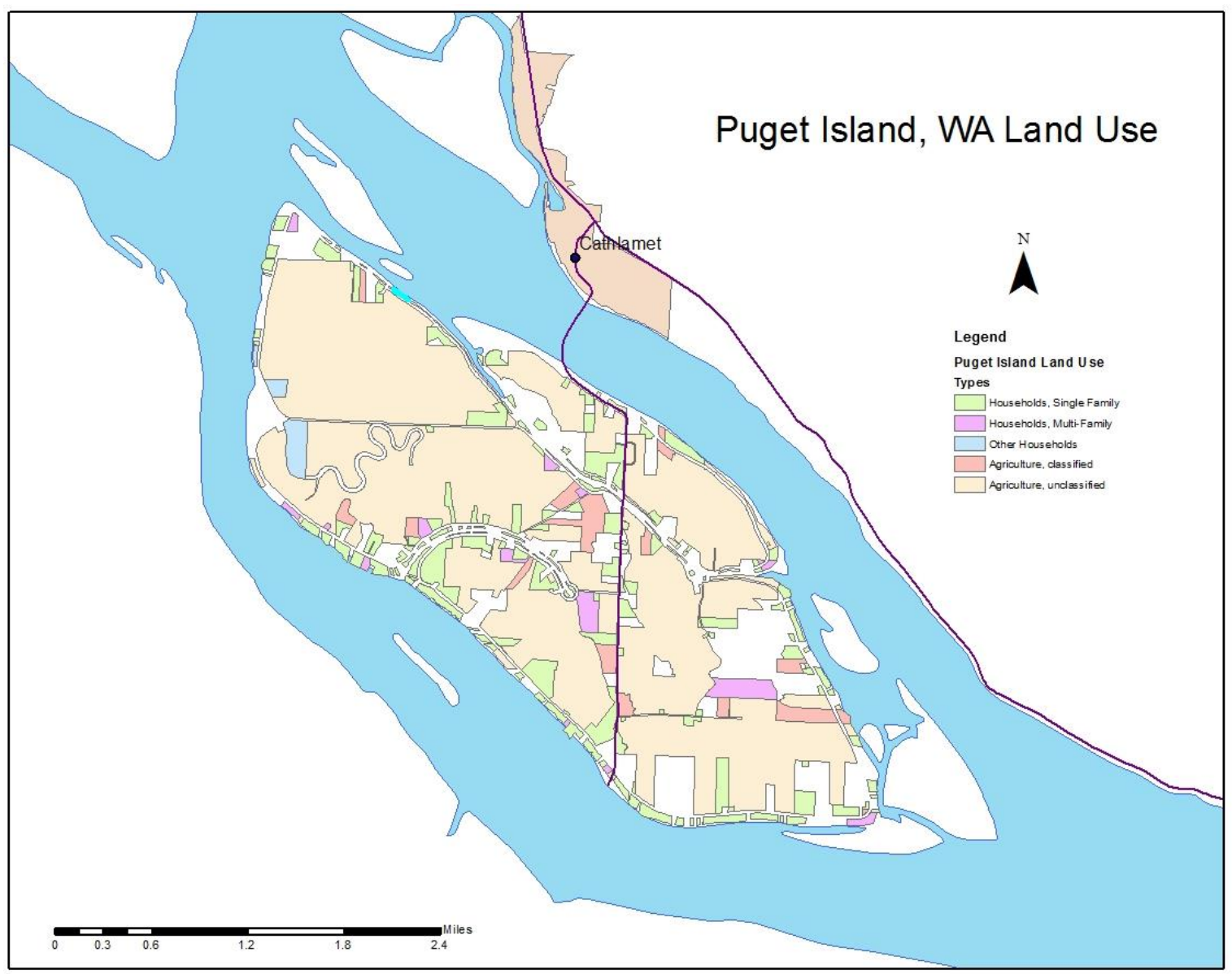

Figure 2 - Map of Puget Island Land Use. Map by Jessica Beutler; data courtesy of Washington State Department of Ecology GIS Technical Services and Washington State Department of Transportation Office of Information Technology. 
Besides overarching federal environmental and land management laws (i.e. Endangered Species Act, Clean Water Act), there are several environmental and land management laws and plans that directly impact management on Puget Island. These include but are not limited to the Columbia River Estuary Regional Management Plan, Department of Ecology Shorelines Management Plan, Comprehensive Solid Waste Management Plan, Comprehensive Flood Hazard Management Plan, and the Washington State Environmental Policy Act.

\section{Reason for Location Selection}

Puget Island was chosen as the location for this study due to the author's personal knowledge of the Island as well as the Island's unique conditions. As it is an island, it is, to some degree, isolated geographically and boundaries on the area are generally clear. Despite this, ecological and human changes and impacts to the island originate on and off the island. As this study looks at cultural values of the environment on Puget Island, the social structure and characteristics of the island also make it ideal for this study. The relative geographic isolation creates a defined social boundary and as the population is considered rural, the social structure of the island may be vulnerable to social changes happening on Puget Island and elsewhere in Wahkiakum County. With an increase in new residents, mostly retirees, and a changing economy, the community of Puget Island is in a transition stage that may impact the relationship between the residents and the environment of Puget Island. 


\section{Literature Review}

The literature cited in this review focuses on community-based environmental management, stakeholder involvement, sense of place, and the role of sense of place in environmental management.

\section{Community-Based Environmental Management}

Ecosystem services enhance social well-being, support local economies, and moderate natural and human activities. Therefore, communities have incentives to play a significant role in the protection of their local environment and often choose to do so. The Environmental Protection Agency (EPA) argues that environmental protection plans developed with incorporation of community-based input have potential to be very effective as they take into account local social, economic, and environmental conditions as well as community values. Environmental protection that is community-based fosters a sense of local problem-solving and encourages longterm accountability and support. (Environmental Protection Agency [EPA], 1997)

There are many advantages of community-based environmental management over other environmental management strategies. Plans developed under this management style incorporate the complexity of both natural and human systems and their relationships (EPA, 1997). Local residents are more likely to work with each other and government agencies towards environmental management goals when they are involved from the beginning of management plans (EPA, 1997). Environmental efforts that are specifically designed for local areas and incorporate community values and priorities lead to more community support, community involvement, and stronger environmental protection (EPA, 2003). It is believed that holistic protection on local scales will lead to environmental protection that is more effective over a longer period of time (EPA, 2003). However, in order to make community-based environmental management effective regular reevaluation is necessary as values, issues, structure, and members of community are dynamic and constantly in a state of change (EPA, 1997; EPA 2002). 


\subsection{Stakeholder Involvement}

The National Environmental Policy Act (NEPA) requires government agencies to incorporate public involvement into decision-making and environmental policy implementation. Government agencies may incorporate more or less public involvement in their strategies; however, NEPA requires a public comment period and opportunities for the public to attend policy hearings at minimum. (EPA, 2014)

A basic definition of a stakeholder is anyone who has an interest in the management issue and has a desire to participate in the decision making process. Stakeholders typically fall under five different categories: people who live, work, or play in the subject area; people interested in the use, non-use, or users of a resource; people interested in decision making processes; people who are financially involved in decisions (i.e. taxpayers for decisions on federal land); and/or representatives of those responsible for resources. (Meffe, 2013)

While many individuals may qualify as stakeholders for any given environmental management situation, not all stakeholders can be involved in decision making processes. Despite this, proper stakeholder processes should follow principles of inclusivity, self-selection, and representation of diversity to the highest possible degree. Stakeholders can have a range of interest and engagement from intense interest and active involvement to casual interest and occasional involvement. Environmental managers can utilize stakeholders in their management processes to varying degrees such as notification (informing stakeholders of proposed activities), review and comment (as required for all Environmental Impact Statements), consultation, and limited partnerships. (Meffe, 2013)

Yosie and Herbst (1998) describe stakeholder involvement as having both advantages and disadvantages for the environmental decision process. Advantages of stakeholder processes include increased transparency and trust between involved parties, a variety of perspectives discovered, and the ability for relationships to form between entities that are beneficial for future management interactions. They also increase the breadth of information available, and oftentimes spark creative solutions. On the other hand, inclusion of stakeholders in the process can 
reduce trust among parties, desired data from stakeholder discussions are not necessarily available, and stakeholders can put pressure on land managers to make less controversial decisions. While the inclusion of both scientific and stakeholder views provide more holistic insight for land managers, both sides can represent opposing strategies of decision-making and views, such as loggers and wildlife biologists in endangered species issues. (Yosie, 1998)

An example of a stakeholder process that experienced both the advantages and disadvantages of stakeholder involvement is the Tualatin River Water Quality Credit Trading case study. The Oregon Department of Environmental Quality and Clean Water Services in Tualatin chose to include stakeholders in developing a plan to reduce pollution and stream temperature in the Tualatin River watershed. Stakeholder involvement increased the time and negotiations needed for the plan to be implemented, but ultimately stakeholder involvement provided critical input that led to the success of the plan. Despite tensions that arose during stakeholder meetings, inclusion of stakeholders prevented potential legal challenge afterwards without involvement. (Oregon Department of Environmental Quality, 2007)

\section{Sense of Place}

While physical geography plays a role in the definition of place, the idea of place is much more complicated when understood as a social construct and as experienced differently by individuals and groups (Shamai, 2005). The way that individuals and groups experience place and their connection to a place can be understood as a "sense of place". Sense of place is subjective in nature. Definitions of sense of place vary, but converge on how and why people define what is most important to them about their local landscape (Cantrill, 2009).

Sense of place is the connection we have to the world around us. It is discussed across a wide range of fields from human geography to anthropology to ecology. Geographers studying sense of place look at how people connect to place and how that connection impacts the relationship they have with that place. Sense of place as a way of looking at human-environment relations is increasingly used to assess environmental management as environmental managers realize the importance of community value systems and community involvement. 


\subsection{Sense of Place and the Environment}

Kaltenborn's (1998) study of sense of place in the Arctic archipelago of Svalbard showed that sense of place does have an impact on the way that residents perceive environmental conditions and respond to impacts (1998). According to the study, residents that live in a place longer have more positive views of their local environment but are more likely to take action to protect it. Impacts to the environment have impacts to a range of environmental values that people hold including aesthetic, cultural, and symbolic values, therefore affecting the relationship that people have with their landscape, or their sense of place. (Kaltenborn, 1998).

The relationship between sense of place and the environment, however, is not solely rooted in social constructs and abstract values. Stedman (2011) argues that the physical landscape can have an impact on the sense of place residents have. In his study of sense of place and lakes in northern Wisconsin he showed, for example, residents were happier where lakes were deeper, clearer, less public, and had less shoreline development. Residents living near lakes that were more developed were more likely to base their sense of place off of social values. Therefore, physical changes to the landscape can have significant impact on the attachment and sense of place that residents have to their environment. (Stedman, 2011)

\subsection{Sense of Place in Environmental Assessment}

Human and social factors are often overshadowed by ecological and economic factors in environmental impact assessments (Kaltenborn, 1998; Larson, et al. 2013). Kaltenborn argues that environmental impact assessments need to address social issues, quality of life, and emotional attachments as these things will impact how residents interact with their surroundings (Kaltenborn, 1998). In other words, environmental protection and management is rooted in human value as humans choose how, why, and what is protected from harmful impacts of human activities. While management strategies can be developed as overarching umbrellas for particular landscapes, it is important to recognize that the implementation of environmental management occurs on a place-based scale. Not 
only are places ecologically and economically different, but places are experienced differently by different groups of people (Shamai, 2005).

\subsection{Measuring Human Values and Sense of Place}

Studies have shown that it is possible to measure sense of place empirically and that sense of place can be distinguished to varying degrees by respondents (Kaltenborn, 1998; Larson, et al, 2013; Shamai, 2005).

While sense of place has been shown to be measurable, there are recognizable aspects of sense of place that make it difficult to incorporate into hard science. One main difficulty is that, as there is no clear definition of sense of place, there is likewise no defined way of measuring or organizing it on a scientific level (Kaltenborn, 1998).

Additionally, there are many uncertainties that go along with sense of place when attempting to measure it purely quantitatively. The measurement of sense of place brings out questions regarding where sense of place comes from and what contributes to it (Shamai, 2005). 


\section{Methodology}

\section{Approach}

Sense of place as a subject has been described as "a very vague concept", one that is important but difficult to study (Shamai, 2005). For this reason, there are many different methodologies that have been used to study sense of place. These fall under two categories of research: qualitative and quantitative. For qualitative research, data is presented in the form of words, pictures, or numerical data that is collected through interviews, observations, etc. to create a story through research (St. Mary's University, 2013). Quantitative research instead uses surveys and questionnaires to collect numerical data that can be analyzed statistically (St. Mary's University, 2013). Quantitative methods for studying sense of place typically include ranking degrees of sense of place. A study conducted in Israel ranked varying levels of sense of place of immigrants and natives based on attachments to varying geographic scales (settlements, region, and state) being negative, neutral, or positive (Shamai, 2005). Other studies such as one conducted with women in Raval, Barcelona utilize both quantitative and qualitative analysis by conducting statistical analysis of demographics but conducting interviews and using other forms of qualitative analysis to define the characteristics of the demographics (Ortiz, 2004).

A study of immigrant versus native sense of place in Israel showed that it is possible to research sense of place empirically; however, problems do arise in using only quantitative analysis for sense of place (Shamai, 2005). As Shamai describes, sense of place can be measured empirically, "however, what contributes to it is not completely clear. The question remains: what creates the sense of place, the perception of physical environment or the perception of the personal and social contact and interaction in the place" (Shamai, 2005). For this reason, several geographers have criticized quantitative analysis of sense of place as quantitative data cannot grasp individuals' experiences (Shamai, 2005).

For the purposes of this research, a qualitative approach to understanding sense of place was used. While conducting interviews takes more time and reduces the number of subjects due to time restrictions, quantitative 
surveys would have been less appropriate to the culture of Puget Island and residents would likely have been less receptive to that form of data collection.

\subsection{Recruitment}

Subjects for interviews were recruited through a "snowball" approach. Interviews began with individuals that were recommended to the author by established informants. From there, each interviewee was requested to provide names of other individuals that they believed should be interviewed. A list of more than forty individuals was recommended for interview in total, with fourteen successful interviews completed.

\subsection{Semi-Structured Interviews}

Interviews with residents were conducted on the Island at the interviewees' homes, the author's family home, or at the local fire department by choice of the interviewee. When more than one interviewee were available to interview, subjects were given the opportunity to interview together (i.e. couples, coworkers). To gain a larger diversity of answers and in response to interview results, a balance of newer and older residents was attempted.

Interviews were conducted in a confidential manner at the discretion of the interviewee. Interviews ranged from nine to forty-five minutes in length and followed a semi-structured interview process. (Basic interview questions can be found in Appendix A). Interviews digressed from the question set when the discussion with the interviewee naturally covered the information sought after or the questions were not appropriate to the discussion.

The goals of the semi-structured interviews were to gather the opinions of residents on the changes of societal, environmental, cultural, and economic conditions on the island; understanding of their sense of place on the island; understanding of environmental issues on the island; and the opinions on the role of government in environmental management on the island. 
Definitions of "sense of place", "connection", "environmental issues", "environmental protection", and "government" were typically left to the interviewees with little explanation from the author in order to have more subjective answers from interviewees.

\section{Data Collection}

\subsection{Timescale}

Familiarity with the island and residents was developed from June 2013 to September 2013. During this timeframe, introductions were made to many of the respondents. Extensive time spent on the island provided deeper context for lifestyles of residents and community function. Interviews were conducted between November 2013 and January 2014.

\subsection{Interviewee Distribution}

Fourteen subjects were interviewed over the course of the research. Interviewees ranged in age from late 20 s to 80s. Gender was relatively balanced with six male subjects and eight female subjects. There was an even distribution of new and established residents, seven of each. Subjects were considered established if they were raised on the island or had lived on the island for at least twenty years. This residency distinction was determined through interviewee identification of a wave of new residents beginning fifteen years ago.

Geographically, most interviewees were expected to be concentrated due to the snowball recruitment approach. As expected, the majority (seven interviewees) own property or live on E Sunny Sands Road, including the recruitment source. Other than this concentration, interviewees were distributed across the island with the exception of the northwest corner of Puget Island. (See Figure 3) 


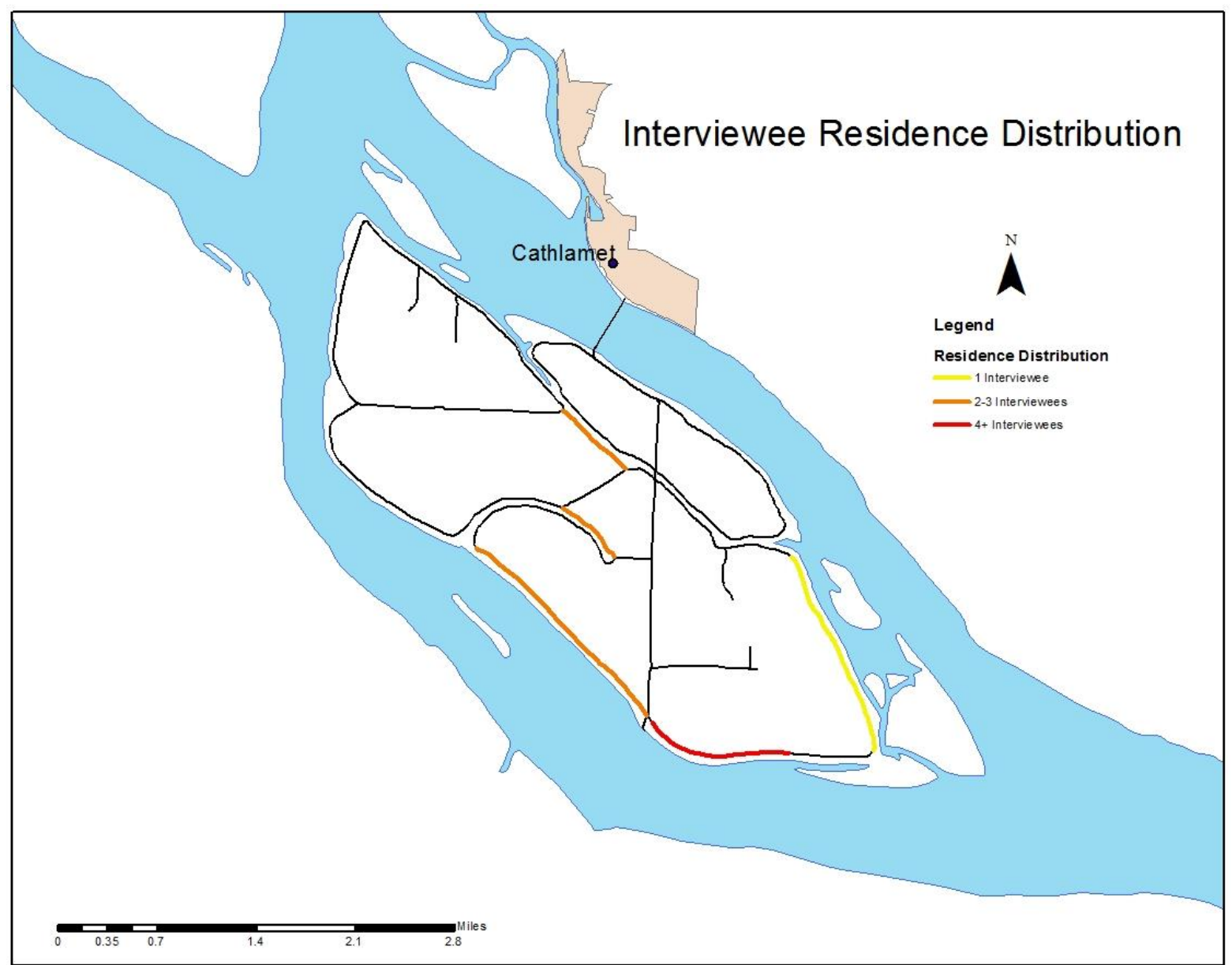

Figure 3 - Map of Interviewee Residence Distribution. Distribution is shown by road on which residents live - red roads indicate residence of four or more interviewees, orange roads indicate residence of two to three interviewees, and yellow roads indicate roads of one interviewee. Map by Jessica Beutler; data courtesy of Washington State Department of Ecology GIS Technical Services and Washington State Department of Transportation Office of Information Technology.

\section{Analysis}

Data from the recorded interviews were transferred into six different survey matrices: basic

information, activities, description of Puget Island residents, values, awareness of environmental issues, and changes to the community. The basic information matrix included time lived on Puget Island, if the interviewee had family established on the Island before living there, why they came to Puget Island, if they felt connected to the island, whether or not they felt residents took care of the island, whether or not the established versus newer resident dynamic was discussed during interview, whether or not Puget Island is worth time to protect, if environmental management of the island is adequate, and 
whether or not the interviewee felt that environmental agencies involved the community in their work. Survey matrices were used to compare and analyze interviews for differences and similarities.

(See Appendix B for full survey matrices.)

After analyzing interview data, a grey literature analysis was conducted based off of information on interviewee awareness of environmental issues and views of adequacy of environmental management. The grey literature analysis was conducted using online database searches to find public information on stakeholder involvement in two identified environmental issues managed by the US Fish and Wildlife Service and the US Army Corps of Engineers. These two environmental issues were selected due to prominence during interviews.

\section{Limitations}

Limitations in data collection are largely rooted in limited accessibility for research. As the research was conducted during the academic calendar and at a significant distance from Portland State University, time to conduct research was extremely limited. As this research relied on the availability of interviewees, it was often difficult to secure interviews during this limited time, typically around holidays. For this reason, many potential interviewees were not available when research could be conducted. Because of this limitation, the number of subjects interviewed was significantly lower than desired.

A related issue was that interviewees were limited in social diversity due to the snowball approach. Restricted time for data collection limited the number of interviewees, and subsequently, diversity. Had more time been allowed, it is expected that more interviewees would have resulted in diversity. 


\section{Findings and Analysis}

\section{Relationship to the Island}

The majority of interviewees stated that they in some way feel a connection to Puget Island or consider it a part of their identity. Ten out of the twelve interviewees answered positively when answering whether or not they felt a connection to the island or if it is a part of their identity. The two negative answers explained their reasoning in reference to not having lived on the island long enough or their whole life. Time lived on the island did not influence all answers of new residents (criteria for distinguishing new and established residents defined in Section 16.2 and 22) as five of the ten positive answers were from new residents.

When asked whether or not residents of Puget Island take care of the land and environment, the majority of interviewees considered the majority to generally take care of the land with the exception of a few residents. Interviewees defined not taking care of the land as accumulating "junk" and/or not maintaining buildings and structures due to lack of regulations on properties. Additionally, interviewees explained that farms were cared for when they covered the majority of the island but that relationship with the land has changed with land use change. Finally, one interviewee explained that the island is comprised of "haves and have nots", where the "have nots" are less likely to take care of the land. Only a single interviewee viewed residents as taking care of the land completely.

Interviewees were also asked to identify any social or environmental changes that they have seen happen on Puget Island during their time there. Six of the fourteen interviewees recognized economic changes to the island such as change in industry (i.e. decreased fishing and decreased logging) and increase in unemployment. Four interviewees recognized agricultural changes (separately from economic changes) such as decrease in farms and changes in crops. Additionally, interviewees identified increased population, more retirees, and beach erosion as changes to the island. 


\section{Resident Values}

Interviewees identified ten different values associated with the island during the interviews. Ten of the fourteen interviewees identified people (community, family, etc.) as a value making it the most frequently discussed value. The river was the second most identified value with a frequency of seven discussions. Small town/ruralness and sereneness/peace each were identified five times. The topics were equally balanced between values concerning societal aspects of Puget Island and environmental aspects (for example, safety as a societal value whereas the river as an environmental value).

Table 1 - Frequency of discussion of values in interviews

\begin{tabular}{|c|c|}
\hline Values & Frequency of Discussion \\
\hline People & 10 \\
\hline River & 7 \\
\hline Small Town/Ruralness & 5 \\
\hline Sereneness/Peace & 5 \\
\hline Proximity to Cities & 4 \\
\hline Family History & 3 \\
\hline Safety & 2 \\
\hline Fishing & 2 \\
\hline Viewscape & 2 \\
\hline Wildlife & 2 \\
\hline
\end{tabular}

\section{Environmental Awareness of Residents}

Among the fourteen interviews, eleven environmental issues and concerns were identified: Columbian White Tail deer, erosion/beach protection, waste, liquid natural gas (LNG) plant, cattle, wetland protection, river protection, infrastructure, fish/fishing industry, noise pollution, and water/air pollution. Of these topics, the issue of Columbian White Tail deer was identified by six interviewees, making it the most frequently discussed topic among interviewees. The Columbian White Tail deer issue was followed by waste (which includes discussion of recycling 
and dumping) with a frequency of five occurrences. Erosion/beach protection, wetland protection, and the previously-proposed LNG plant were discussed by four interviewees each.

Table 2 - Frequency of discussion of environmental issues or concerns in interviews

\begin{tabular}{|c|c|}
\hline Environmental Issue/Concern & Frequency of Discussion \\
\hline Columbian White Tail Deer & 6 \\
\hline Waste (Recycling/Dumping) & 5 \\
\hline Erosion/Beach Protection & 4 \\
\hline Wetland Protection & 4 \\
\hline LNG Plant & 4 \\
\hline Infrastructure (i.e. Septic tanks) & 3 \\
\hline Cattle (Population, Care) & 2 \\
\hline River Protection & 1 \\
\hline Fish/Fishing Industry & 1 \\
\hline Noise Pollution & 1 \\
\hline Pollution & 1 \\
\hline
\end{tabular}

Five of the interviewees expressed that the environment of Puget Island is worth personal and government time and money to protect. One interviewee, however, elaborated that the environment is valuable but it does not always feel like it is worth the time because of problems the interviewee had with environmental management agencies such as the Army Corps of Engineers in the past.

\section{Environmental Protection on Puget Island}

Nine of the fourteen interviewees provided answers to whether or not they believed that environmental protection on the environment was adequate. The definition of "environmental protection" was left up to the discretion of the interviewee but can be interpreted as referring to actions by government agencies at local and federal level. Five of those interviewees believed that there is adequate environmental protection. One of the 
interviewees that answered positively, however, explained that while environmental protection is adequate, it is too political. The four interviewees that answered negatively cite overmanagement of Columbian White-Tailed Deer and improper management of beaches (specifically, management of the beach erosion). (For further discussion of Columbian White-Tailed Deer management, see section 17.1.)

Six interviewees also provided opinions on whether or not they believed that these agencies are involved in the community. Of these, four believed that agencies do not adequately involve the community. One of these interviewees desires more public hearings and town hall meetings (with emphasis on meetings at times that work for community members). Another believes that environmental management agencies do not listen to community members and do not take experience into account when making management decisions, specifically citing the issue of Columbian White Tail deer. Criticism was made over translocation and restoration efforts that do not consider Puget Island as suitable habitat for the deer. Citing the beach erosion issue, another interviewee explained that the federal agencies, such as the Army Corps of Engineers, are actually preventing proper environmental protection by creating bureaucratic "stumbling blocks" that make progress difficult. The remaining two interviewees that recognize adequate agency involvement expressed that community involvement surfaces when there is an immediate issue and have personally seen involvement.

\section{Established Versus Newer Residents}

Over the course of the interviews, half of the interviewees discussed a dichotomy of new and established (often described as "old") residents. Established residents were typically understood to be residents that were raised on the island or had been living on the island for more than twenty years. New residents were considered residents that are a part of a wave of new residents that began moving to the island approximately fifteen years ago.

The majority of these new wave residents consist of retirees, many of which have earned the nickname of "snowbirds" for residing on the Island only during the warm months and elsewhere during the colder months. The term snowbird is used by new and established residents whether or not residents are on the Island seasonally or 
year-round. Established residents explained that new residents come for the rural living, community, fishing, and proximity to cities and other resources. This observation was reflected in the values new residents described in their interviews.

Conflict and contention between the two types of residents was recognized by established residents during the interviews. One established resident stated that new residents connect to the Island differently than established residents and come from a different way of life. Another resident explained that conflict comes from the different values that newer residents hold. For example, while residents have a connection to the river regardless of length of residency, newer residents connect to the river for its intrinsic value instead of for economic values as had been previously the case in the Island's culture.

Conflict arises from established residents being unwelcoming of change. One resident explained that established residents do not want newer residents to become involved in the community as they see the newer residents as agents of change to the old way of life on the island. Despite this, one established resident explained that newer residents are not involved enough and would bring new energy to community groups and dialogue on the island. Of the six interviewees who said they participated in community activities, two were newer residents. Another newer resident stated that she does not participate because she is a newer resident. Other residents explained that newer resident involvement would lead to changes that would protect the environment of Puget Island, as these residents moved to the Island with respect for it, whereas established residents take the environment for granted and want to continue with habits they have always been allowed to have (i.e. junk cars on properties).

While this conflict was discussed by many established residents, none of the interviewees themselves appeared to be resentful or negative towards newer residents. Therefore, it is difficult to judge how widespread this resentment is among the established residents. 


\subsection{Comparison of Values}

As expected from discussion with established residents, the river and peacefulness were significant values for new residents. Of the seven interviewees that recognized the river as a value, six of them were new residents. For the value of peacefulness, four of the five interviewees were new residents. Overall, newer residents come for the river, quiet, small town life/qualities, and proximity to cities. On the other hand, established residents overwhelmingly value the people and community, accounting for seven of the ten interviewees that valued people.

\subsection{Comparison of Environmental Awareness}

In comparing the environmental awareness of new and established residents, the most commonly addressed environmental concern, Columbian White Tail Deer, was evenly split between new and established residents. The most common topics for established residents were the deer and infrastructure. Of the next most discussed topics after Columbian White Tail Deer, new residents accounted for four of five interviewees for waste issues, all four for erosion/beach protection, three of the four for the LNG plant, and three of the four for wetland protection. On average, newer residents recognized three different environmental issues and concerns. Established residents recognized between one and two environmental issues and concerns on average.

\section{Resident Recommendations}

During the course of the interviews, residents made recommendations on how to improve the economy and environmental conditions on Puget Island. Two residents separately recommended that regulations need to be made that restrict hoarding of waste on properties. Typically, this waste takes the form of used cars and other scrap metal. One of these residents explained that "Puget Island could be a [tourist] destination without the junk".

Additionally, recommendations were made to better represent residents in Wahkiakum County. Specifically, recommendations were made to get newer residents involved in the community socially and politically in order to add a wider range of thinking into community dialogue. 
Finally, recommendations to improve the economy include incorporating the assets of the local environment. One resident believes that the environment of the area should be promoted to bring tourism to the area. Along with this, Wahkiakum County should make efforts to bring the film industry to the area to boost the economy.

\section{Public Involvement in Environmental Management}

After assessment of resident understanding of environmental issues and criticism of public involvement and management in regards to Columbian White-Tailed Deer management and beach erosion, further research was conducted into the management and public involvement strategies in these areas.

\subsection{Columbian White-Tailed Deer Management}

The Columbia River distinct population segment of Columbian White-Tailed Deer are listed as endangered on Federal and State levels due to decreasing floodplain habitat from agricultural and urban development (Washington Department of Fish and Wildlife [WDFW], 2013). Currently the population is found on Columbia River islands, including Puget Island, and adjacent Oregon and Washington shores in the Columbia River estuary (See Figure 4) (WDFW, 2013). A population of between 50 and 170 individuals inhabit Puget Island, however, the Island is not considered secure habitat as the island is mostly private land (WDFW, 2013; USFWS, 2014a). The main population in the area resides in the Julia Butler Hansen National Wildlife Refuge (JBH) where restoration efforts are focused. However, population has decreased in the refuge due to flooding, disease, and hybridization with black-tailed deer (WDFW, 2013). To augment these issues, 234 deer in total have been translocated from Puget Island occurring in 2006 and 2013 (WDFW, 2013). 


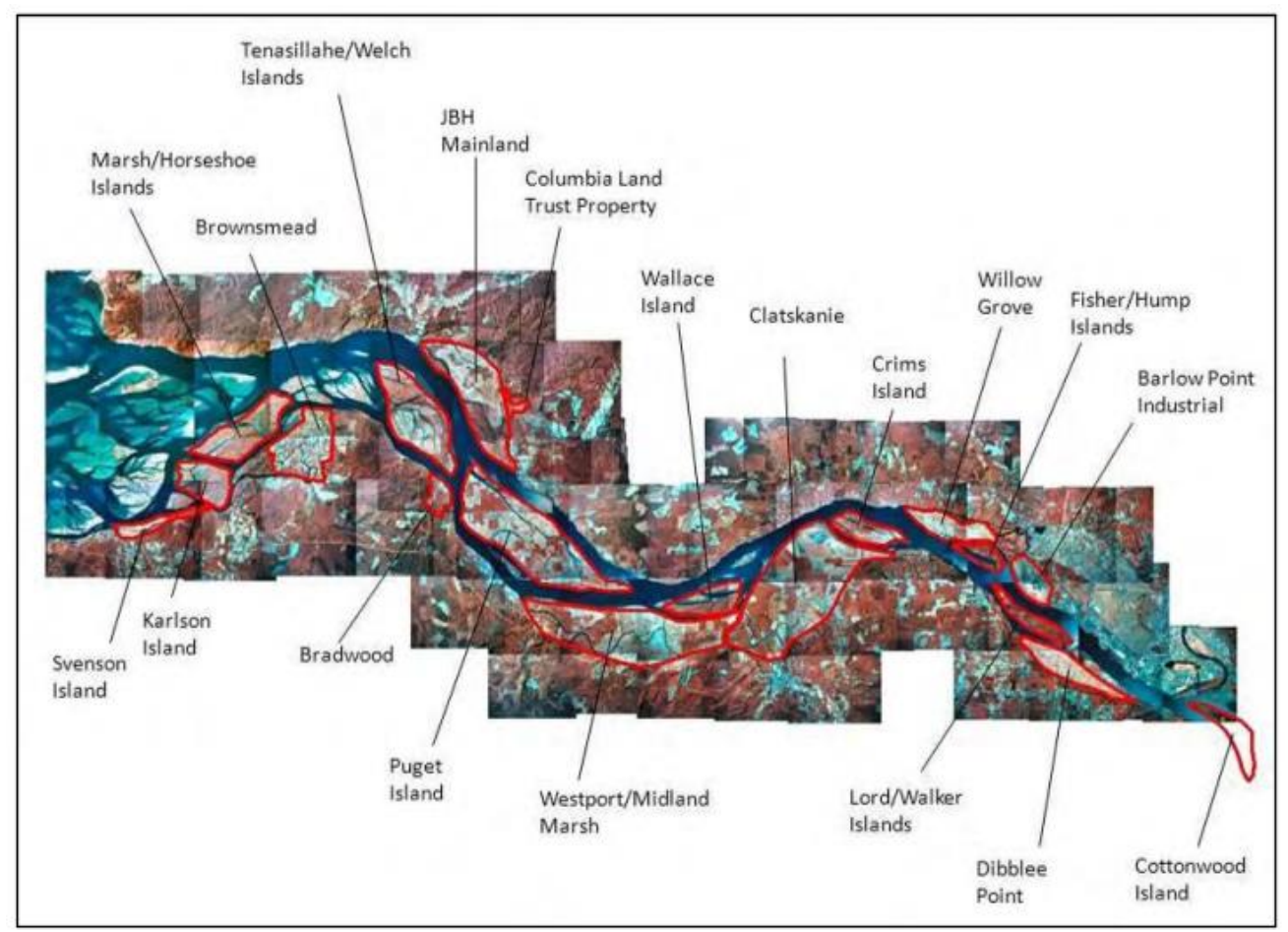

Figure 4-Range of Columbian White-Tailed Deer in the Columbia River estuary (US Fish and Wildlife Service and Washington Department of Fish and Wildlife, 2011).

With the discovery of weak dikes in JBH, USFWS has proposed to translocate approximately half of the deer from JBH to the Ridgefield National Wildlife Refuge and up to 35 deer from Puget Island to Cotton Wood Island (See Figure 5) (USFWS, 2014a). Study of the deer population estimates that translocation of deer from Puget Island will provide a slight social benefit due to reduced animal damage (USFWS, 2014a). 


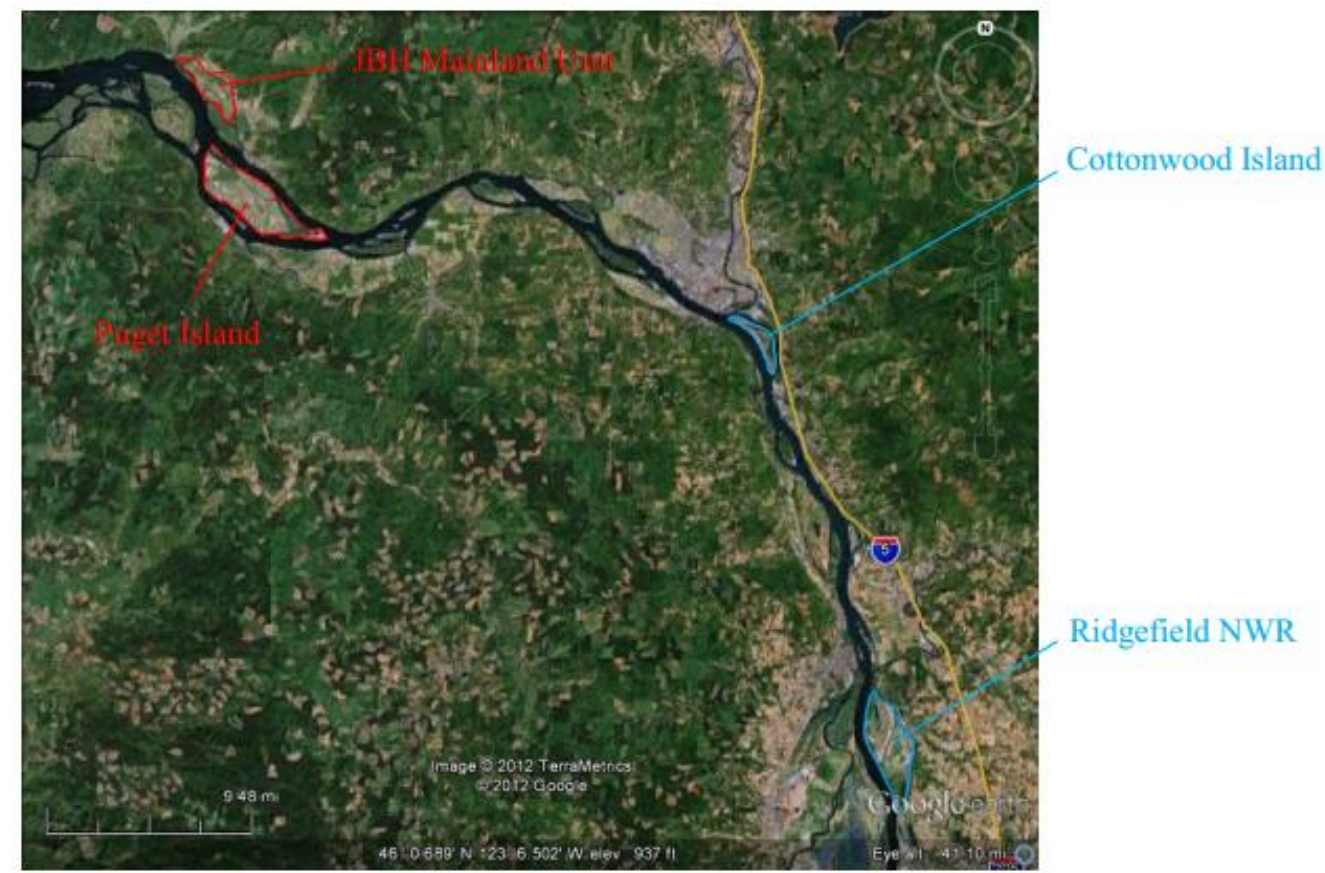

Figure 5 - Capture sites of Columbian White-tailed Deer (JBH Mainland Unit and Puget Island) and release sites (Cottonwood Island and Ridgefield National Wildlife Refuge [NWR]) (USFWS, 2014).

The 2014 Columbian White-tailed Deer Translocation Final Environmental Assessment solicited public involvement by outreach to landowners and elected officials surrounding Ridgefield, and public information meetings in January 2013 in Ridgefield, WA and Sauvie Island, Oregon.

Additionally, a 30-day comment period to review the Draft Environmental Asssessment for the Proposed Translocation of Columbian White-tailed Deer from Puget Island to Ridgefield National Wildlife Refuge and Julia Butler Hansen Refuge occurred between December 12, 2013 to January 12, 2014 (USFWS, 2014a). Many of these comments related to Puget Island, however, it is not discernible from the report whether or not the commenters are residents of Puget Island or which comments were made by which person. Eleven individuals and entities in total provided comments, all of which were responded to by USFWS (USFWS, 2014b).

Eight of the comment summaries and responses directly regarded Puget Island. USFWS responded to comments suggesting "that farmed lands such as Puget Island, are better for deer than Refuge lands, and that deer do better on their own without management" by explaining that agricultural and residential lands can provide habitat but prevent the optimal population densities and are not viable for restoring the species. Another set of comments 
were concerned that USFWS was not properly estimating the population but the USFWS explained that since Puget Island is more open due to development, it is easier to see deer and may appear that there is a larger population than in reality. One comment expressed that there are too many deer on Puget Island, that they cause property damage, and that they are a vehicle safety hazard. The USFWS explained that removal would relieve these issues. Sets of comments both supported and opposed deer removal from Puget Island, to which the USFWS responded that the removal will temporarily decrease the population, relieving issues caused by the deer but would not completely remove the population. Another comment expressed that deer should be removed from Douglas County instead of Puget Island but USFWS explained that that would require quarantine and other processes that are not necessary with Puget Island deer. Remaining comments discussing Puget Island referred to hunting deer on Puget Island, Puget Island deer breeding, and confusion over translocation procedures. (USFWS, 2014b)

Two different comments were made about the public involvement process. First, a public meeting was requested in Cathlamet to supplement public meetings held in Ridgefield. USFWS explained that no formal meetings have been held for environmental assessments regarding the deer and that the meetings in Ridgefield and Sauvie Island were informational meetings about Columbian White-tailed Deer. Additionally, members of the public had an opportunity to speak at a workshop for Wahkiakum County Commissioners in December 2013. The second comment asked how the public would be informed about deer removal to which USFWS responded that there has been ongoing media coverage in local media and social media; informational posters were posted at Ridgefield, Cottonwood Island, and the Julia-Butler Hansen Refuge; presentations were made to the Safari Club International and Oregon Hunters Association; and USFWS will continue outreach efforts during translocations. (USFWS, 2014b)

Comments were made on the environmental assessment that did not relate directly to Puget Island but were similar to commentary made by interviewees or otherwise gathered from Puget Island residents. These comments were regarded as incorrect by USFWS, however, were understood to be fact by commenters both in the environmental assessment and interviewees. The comments regarded as incorrect included: significant deer population decreases are due to fences preventing deer from retreating from flooding waters, high mortality in 
prior year's translocation to Ridgefield, that translocations in the past have been unsuccessful, and that the emergency relocation earlier in 2013 was unnecessary. (USFWS, 2014b)

\subsection{Beach Erosion}

Pile dikes were built on the south side of Puget Island to direct water currents and keep the shipping channel clear of sand (BWCC, 2008). However, the pile dikes have had the unintentional consequence of creating strong eddies along the south shorelines of Puget Island, leading to the erosion of beaches and threatening beachfront properties (BWCC, 2008). In 2002, the Pacific International Engineering Report "Projects and Solutions to Water Resource Problems on the Lower Columbia River" recommended beach nourishment to solve beach erosion on Puget Island (Wahkiakum County, 2010). Wahkiakum County works with the Army Corps of Engineers, which maintains the pile dikes to secure ship passage on the Columbia, to solve the erosion issue (Board of Wahkiakum County Commissioners, 2008). The Water Resources Development Act of 2004 authorized the Army Corps of Engineers to implement erosion control measures on Puget Island (U.S. Senate, 2004). This order authorized a onetime replenishment between river miles 38 and 47 to "to protect economic and environmental resources in the area from further erosion“ (U.S. Senate, 2004). In November 2008, the US Army Corps of Engineers placed 265,373 cubic yards of dredged material along 3,300 feet of shoreline on Puget Island (Department of Ecology, 2008).

Documentation of public involvement in the project is non-existent, undocumented, or unpublished. An interview with an involved resident revealed that public involvement from 2007-2008 included door-to-door public notices from Wahkiakum County and resident signatures to approve sand renourishment. The public notices provided residents with an opportunity to send in public comments. Additionally, residents were welcome to speak at County Commissioner meetings to express concerns.

According to the Joint Aquatic Resource Permit Application for the project, the shoreline was expected to last 20 years upstream and ten years downstream of the pile dikes. However, residents expressed concern that erosion of the beach has already reached levels of concern after only six years. From 2013 to 2015, a new Comprehensive 
Shoreline Management Program is being written and will likely include the status of erosion along Puget Island shores with recommendations on further steps (BWCC, 2014). Currently, residents affected by beach erosion are developing plans and collecting signatures to appeal to Wahkiakum County for re-pumping of sand along Puget Island shores. The erosion issue is a regular point of discussion in Wahkiakum County Commissioner meetings and debate about the problem of beach erosion appears to be increasing due to resident pressure. 


\section{Discussion}

Puget Island is a community undergoing significant economic, social, cultural, and environmental change. As was shown through interviews with residents, the social fabric of the community is changing along with the changing economic conditions of the area. With fewer economic opportunities, Puget Island is moving towards becoming a community with an increasing proportion of new residents who work elsewhere or are retired. Both newer and established residents recognize these changes that are happening, and according to interviewees, many of the established residents are pleased with this change.

Established residents are not incorrect when they view newer residents as having different values. The value assessment of the residents shows that newer residents place greater importance on environmental values than social values. Additionally newer residents appear to have a broader understanding of environmental issues. This may be attributed to newer residents being attracted to the island for its environmental value. They may be more aware of threats to those values because it is the reason they moved there. Along those lines, it makes sense that established residents might feel threatened by newer residents as they place more value on the social aspects of the island.

This trend of established residents placing less value on the environment than newer residents is not unique to Puget Island. Kaltenborn's work in Svalbard showed that respondents with strongest sense of place are least likely to recognize environmental disturbances whereas respondents with weaker sense of place are more critical of environmental conditions (Kaltenborn, 2009). Research on sense of place in the Lake Superior basin showed that the longer a resident lives in an area, the less likely they are to incorporate the natural environment into their definition of their sense of place (Cantrill, 2009). Additionally, research has found that the more time a resident resided in rural regions, the more important social values became to sense of place than environmental values (Cantrill, 2009). 
However, those with a strong sense of place are less indifferent and more committed to solving environmental problems that arise (Kaltenborn, 2009). Despite newer residents leaning towards environmental values and having greater awareness of environmental issues, established residents are more heavily involved in community activities. If the Puget Island residents were to better engage newer residents or if newer residents sought out more opportunities to become involved, there would be potential for more discussion of environmental issues raised by newer residents.

It was expected that residents would be much more critical of environmental protection of the island than findings showed. Interviewees were split on whether or not they viewed environmental protection to be adequate. However, those who had negative opinions were extremely critical. This may be attributed to education on environmental issues and/or community involvement of the interviewee. While interviewees were divided on adequacy of environmental management, many felt that agencies active in the area were not properly involving the community in decisions.

Two of the major focuses of environmental concern were that of the Columbian White Tailed Deer and beach erosion on Puget Island. Issues raised by residents on the deer centered around mismanagement of the deer in the Julia Butler-Hansen Refuge, which is located across the river, creating management issues on the island. Many of these concerns were reflected in public comments made about the Environmental Impact Statement (i.e. drowning of deer) but were explained by USFWS as being unfounded. This shows that there is a gap in education and environmental understanding between environmental managers and residents. While USFWS allows for public comment periods under the requirements of NEPA, it is clear from discussing with residents that a more hands-on engagement between USFWS and residents would be ideal. Some opinions expressed in the public comments to the USFWS regarding Columbian White-Tailed deer were not represented in the interviews that took place during this research. Therefore, it is clear that the scope of this study was narrow and should be expanded upon to better understand sense of place and opinions of the community. 
The second issue, beach erosion, appears to have had more public involvement as this issue directly impacts the safety of residents and protection of their properties. While there appears to be more involvement from public records and discussion with impacted property owners, this is an issue that is highly political and bureaucratic. The beach nourishment of 2008 took as long as six years of negotiating and permitting to be implemented only to have beaches erode to pre-2008 levels in less than six years. 


\section{Conclusion}

Sense of place is changing with the changes in the community on Puget Island. However, the change to a newer community does not mean a loss of sense of place, but simply a shift in the emphasis that residents place on different values. Specifically, if trends from this study persist and are representative, the community on Puget Island will increasingly value the environment over social aspects. Alternatively, newer residents may come to place higher importance on social values as they become established residents. Additionally, newer residents appear willing to become involved in the community and would like to be included on environmental management decisions. Therefore, it would be in the best interest of environmental management agencies to work closely with

the community. With changes that are happening in the fabric of the community, environmental managers need to incorporate new values and new perspectives into their understanding of community structure and attitudes on Puget Island.

Environmental management agencies, while attempting to reach out to the public, are currently not adequately educating the public on Puget Island. Negative attitudes towards environmental management agencies suggest that attempts at public involvement are not enough. In order to not alienate the public, environmental management agencies need to work on including residents earlier on in the management process.

From discussion with residents, it appears that environmental protection is left to the agencies and county when there are no issues at hand. When there is a large issue, such as the Columbian White-tailed Deer or beach erosion, the community is highly vocal but lacks a structure for these residents to become involved beyond public comment. Therefore, it is suggested that concerned residents of Puget Island develop a community structure to become more involved in local environmental protection. This will provide a foundation for community voice and action when issues arise. Such an organization could provide stronger environmental education and rally community involvement of both newer and established residents. 


\section{Bibliography}

Board of Wahkiakum County Commissioners [BWCC]. (2008). Comprehensive Plan for Wahkiakum County, Washington. Retrieved from: http://s3.amazonaws.com/zanran_storage/www.co.wahkiakum.wa.us/ContentPages/42946937.pdf

Board of Wahkiakum County Commissioners [BWCC]. (2014). Regular Meeting Agenda January 7, 2014. Retrieved from: http://www.co.wahkiakum.wa.us/depts/bocc/documents/AgendaPacketJanuary7-Media.pdf

Cantrill, James G. (1998). The environmental self and a sense of place: Communication foundations for regional ecosystem management. Journal of Applied Communication Research, 26:3, 301-318. Retrieved from: http://www.tandfonline.com/doi/pdf/10.1080/00909889809365509

Department of Ecology. (2008). Water Quality Certification. Retrieved from: http://www.ecy.wa.gov/programs/sea/fedpermit/pdf/Decisions/SWRO/200700718\%20WQC\%205316.pdf

Environmental Protection Agency [EPA]. (2014). National Environmental Protection Act: Basic Information. Retreived from: http://www.epa.gov/compliance/basics/nepa.html

Environmental Protection Agency [EPA]. (1997). Community-Based Environmental Protection: A Resource Book for Protecting Ecosystems and Communities. Retrieved from: http://www.epa.gov/care/library/howto.pdf

Environmental Protection Agency [EPA]. (2003). Evaluation of Community-Based Environmental Protection Projects: Accomplishments and Lessons Learned. Retrieved from: http://www.epa.gov/care/library/evaluation.pdf

Environmental Protection Agency [EPA]. (2002). Community Culture and the Environment: A Guide to Understanding a Sense of Place. Retrieved from: http://www.epa.gov/care/library/community_culture.pdf

Kaltenborn, B.P. (1998). Effects of sense of place on responses to environmental impacts. Applied Geography. 18, 169-189.

Larson, S., De Freitas, D. M., Hicks, C. C. (2013). Sense of place as a determinant of people's attitudes towards the environment: Implications for natural resources management and planning in the Great Barrier Reef, Australia. Journal of Environmental Management. 117, 226-234.

Martin, Irene. (1997). Beach of Heaven: A History of Wahkiakum County. Pullman: Washington State University Press

Meffe, G.K., Nielsen, L.A., Knight, R.L., Schenborn, D.A. (2013). Ecosystem Management. Island Press.

Nature Conservancy. (2014). Robert W. Little Nature Preserve in Washington. Retrieved from: http://www.nature.org/ourinitiatives/regions/northamerica/unitedstates/washington/placesweprotect/p uget-island.xml

Oregon Department of Environmental Quality. (2007). Water Quality Credit Trading in Oregon: A Case Study Report. Retrieved from: http://www.deq.state.or.us/wq/trading/docs/wqtradingcasestudy.pdf

Ortiz, Anna, Maria Dolors Garcia-Ramon and Maria Prats. (2004). Women's use of public space and sense of place in the Raval (Barcelona), GeoJournal 61: 219-227.

Shamai, S., \& llatov, Z. (2005). Measuring Sense of Place: Methodological Aspects. Journal of Economic \& Social Geography, 96(5), 467-476.

Stedman, R.C. (2011). Is it Really Just a Social Construction?: The Contribution of the Physical Environment to Sense of Place. Society and Natural Resources: An International Journal, 16(8), 671-685.

St. Mary's University. (2013). Qualitative vs. Quantitative Research. SMU Twin Cities Library. Retrieved from: http://www2.smumn.edu/deptpages/tclibrary/tutorials/finding/qualitative.php

U.S. Census Bureau. (2010). American Fact Finder: Puget Island CDP, Washington. Retrieved from: http://factfinder2.census.gov/faces/tableservices/jsf/pages/productview.xhtml?pid=DEC_10_DP_DPDP1

U.S. Senate. 108th Congress, 2nd Session. [S. 2554], Water Resources Act of 2004. Washington: Government Printing Office, 2004.

US Fish and Wildlife Service [USFWS]. (2010). Lewis and Clark National Wildlife Refuge and Julia Butler Hansen Refuge for the Columbian White-tailed Deer: Draft Comprehensive Conservation Plan and Environmental Impact Statement. Retrieved from: http://www.fws.gov/pacific/planning/main/docs/WA/jbhIc/Draft\%20CCP\%20EIS/4\%20Chapt\%204\%20Biological\%20Environment\%20110409r.pdf 
US Fish and Wildlife Service [USFWS]. (2014a). Columbian White-Tailed Deer Translocation Final Environmental Assessment. Retrieved from http://www.fws.gov/jbh/pdf/Translocation/2014/CWTD_2014_translocation_EA_Final.pdf

US Fish and Wildlife Service [USFWS]. (2014b). Columbian White-Tailed Deer Translocation Final Environmental Assessment: Appendix A Public Comments. Retrieved from https://www.fws.gov/jbh/pdf/Translocation/2014/Appendix\%20A.\%20Response\%20to\%20Comments_fin al.pdf

US Fish and Wildlife Service and Washington Department of Fish and Wildlife. (2011). Columbia River Distinct Population Segment of the Columbian white-tailed deer (odocoileus virginianus leucurus) 5-Year Review: Summary and Evaluation DRAFT.

Wahkiakum County. (2010). Comprehensive flood hazard management plan. Retrieved from: www.co.wahkiakum.wa.us/depts/pw/building.htm

Washington Department of Fish and Wildlife [WDFW]. (2013). Threatened and Endangered Wildlife in Washington: 2012 Annual Report. Listing and Recovery Section, Wildlife Program, Washington Department of Fish and Wildlife, Olympia. 40-43. Retrieved from http://wdfw.wa.gov/publications/01542/wdfw01542.pdf

Yosie, Terry F., and Timothy D. Herbst. (1998). Using Stakeholder Processes in Environmental Decisionmaking. Rep. Global Development Research Center. Retrieved from: http://www.gdrc.org/decision/nr98ab01.pdf 


\section{Appendix A - Interview Questions Outline}

\section{Interview questions outline}

- How long have you lived on the island?

- If not their whole lives: What made you move to Puget Island?

- How long do you think you will live on the island?

- When not working, are there any activities that you like to do on Puget Island?

- Do you participate in any community activities/organizations on Puget Island?

- How would you describe the people that live on Puget Island?

- What brings people to Puget Island?

- What is it that keeps you living on Puget Island? / What is your favorite thing about Puget Island?

- Has that changed at all during the time that you have lived here?

- What are the things that you value most about the island?

○ Why?

- Do you think that you could find those things anywhere else?

- Do you think that your values are threatened by anything, if so, what?

- Besides any threats you already mentioned, do you think there are any threats to Puget Island, if so, what?

- How would you describe your connection to the Island?

$\circ \quad$ Do you consider Puget Island to be a part of your identity, how so?

- Would you say that you have an emotional attachment to the island?

- Would you consider yourself aware of environmental or ecological issues of Puget Island?

- If so, what do you know about/understand?

- If not, is there any reason you consider yourself unaware of the issues?

- Do you think that there is adequate environmental protection on Puget Island?

$\circ$ If not, how could it be improved? What areas should be focused on?

- If you were an environmental manager, what would be your priority to protect, restore, or manage?

- Do you think that it is worth time or money to protect the environment of Puget Island?

- How has the island changed in the time that you have lived here?

- How do you think the island will change in the future?

- Do you think those are positive changes?

- Will those changes affect your connection to the island?

- Who would you recommend for interviews? 


\section{Appendix B- Survey Matrices}

\section{Basic Information}

\begin{tabular}{|c|c|c|c|c|c|}
\hline Interview & \begin{tabular}{|l} 
Time \\
Lived on \\
PI \\
\end{tabular} & $\begin{array}{l}\text { Family on } \\
\text { PI first }\end{array}$ & Came to PI b/c: & Connected to island? & Residents take care of land? \\
\hline A & 6 years & Yes & Familiarity & Yes & $\begin{array}{l}\text { Depends on owners; PI is comprised of } \\
\text { haves and have nots }\end{array}$ \\
\hline B & 46 years & No & Work & Yes - long history on the island & $\begin{array}{l}\text { Mostly - old timers took care of farms, } \\
\text { respect of land has changed }\end{array}$ \\
\hline C & 8 years & No & Retirement & $\begin{array}{l}\text { Yes - Farmer's Market allowed them } \\
\text { to connect to island and community }\end{array}$ & $\begin{array}{l}\text { Mostly - People care about land but lack of } \\
\text { regulations allow people to have junky } \\
\text { properties }\end{array}$ \\
\hline D & 8 years & No & Retirement & $\begin{array}{l}\text { Yes - Farmer's Market allowed them } \\
\text { to connect to island and community }\end{array}$ & $\begin{array}{l}\text { Mostly - People care about land but lack of } \\
\text { regulations allow people to have junky } \\
\text { properties }\end{array}$ \\
\hline $\mathrm{E}$ & 65 years & Yes & Born & Yes & $\begin{array}{l}\text { Mostly - people aware of env issues and } \\
\text { rules you have to follow }\end{array}$ \\
\hline $\mathrm{F}$ & 40 years & No & Work & Yes & N/A \\
\hline G & 22 years & No & Raise children & $\begin{array}{l}\text { Somewhat - People who have lived } \\
\text { there whole life are more } \\
\text { connected }\end{array}$ & Yes \\
\hline $\mathrm{H}$ & 29 years & Yes & Born & $\begin{array}{l}\text { Yes-Connected through living } \\
\text { there whole life, family history }\end{array}$ & Yes; a few that don't take care of property \\
\hline I & 6 years & No & $\begin{array}{l}\text { Retirement/New place/ } \\
\text { Close to family }\end{array}$ & N/A & $\begin{array}{l}\text { Yes and no - livestock owners not caring } \\
\text { well enough for livestock, people take care } \\
\text { of river }\end{array}$ \\
\hline J & 35 years & No & Work & $\begin{array}{l}\text { Yes and no - Personal roots not on } \\
\text { island but ultimately part of identity }\end{array}$ & N/A \\
\hline K & 6 years & No & Wife's family & Yes - Part of identity & N/A \\
\hline $\mathrm{L}$ & 6 years & No & Property Near River & Yes - fishing community & Yes; a few that don't take care of property \\
\hline M & 6 years & No & Property Near River & $\begin{array}{l}\text { No - need to be connected to } \\
\text { community for that }\end{array}$ & Yes; lax regulations though \\
\hline $\mathrm{N}$ & 40 years & Yes & Born & N/A & $\begin{array}{l}\text { Generally; few that keep junk cars; } \\
\text { correlates to economy }\end{array}$ \\
\hline
\end{tabular}

\begin{tabular}{|l|l|l|l|l|}
\hline Interview & Older vs. Newer brought up? & $\begin{array}{l}\text { Worth time and money } \\
\text { to protect? }\end{array}$ & EnvMgmt Adequate? & Agencies involved in community \\
\hline A & $\begin{array}{l}\text { Yes; newer ppl here b/c of respect } \\
\text { for PI, want to protect; older do } \\
\text { what they want }\end{array}$ & $\begin{array}{l}\text { Yes; need to preserve PI, } \\
\text { not taking deer off, } \\
\text { remove invasives, WC } \\
\text { should take action }\end{array}$ & Yes but political & $\begin{array}{l}\text { Not enough; some meetings; need } \\
\text { meetings that work for everyone }\end{array}$ \\
\hline B & $\begin{array}{l}\text { Yes - new residents connect to island } \\
\text { differently, used to a different way } \\
\text { of living, not farmers }\end{array}$ & $\begin{array}{l}\text { Yes - worth personal and } \\
\text { govt time and money }\end{array}$ & $\begin{array}{l}\text { Yes - trying to protect } \\
\text { the environment }\end{array}$ & N/A \\
\hline Yes - Older residents most active, \\
$\begin{array}{l}\text { nw residents not as active but } \\
\text { would bring new energy }\end{array}$ & N/A & N/A & $\begin{array}{l}\text { Community comes together when there } \\
\text { is a pressing issue; Groups like Columbia } \\
\text { Riverkeepers look out for the island and } \\
\text { involve community }\end{array}$ \\
\hline D & N/A & N/A & N/A & N/A \\
\hline E & N/A & N/A & N/A & N/A \\
\hline F & N/A & & $\begin{array}{l}\text { Yes - Much more so } \\
\text { than 20 years ago. }\end{array}$ & N/A \\
\hline & N/A & N/A & $\begin{array}{l}\text { Not enough - people that experience } \\
\text { have better understanding of land and } \\
\text { wildlife; should listent to residents at } \\
\text { meetings and take into account the } \\
\text { experience of residents }\end{array}$ \\
\hline
\end{tabular}




\begin{tabular}{|c|c|c|c|c|}
\hline $\mathrm{H}$ & N/A & N/A & $\begin{array}{l}\text { No - wrongly } \\
\text { managing deer }\end{array}$ & Not enough \\
\hline I & N/A & Yes & N/A & N/A \\
\hline $\mathrm{J}$ & $\begin{array}{l}\text { Yes - new retirees last } 10-15 \text { yrs } \\
\text { /snowbirds vs old residents raised } \\
\text { here or lived there long time; can get } \\
\text { contentious; o/n different values, } \\
\text { ores take env for granted } * * * \text { etc }\end{array}$ & Yes & Yes & \\
\hline K & $\begin{array}{l}\text { Yes - Economy has aged community } \\
\text { and attracted retirees; now a } \\
\text { bedroom community }\end{array}$ & $\begin{array}{l}\text { Yes and no - "hitting the } \\
\text { wall" with organizations } \\
\text { like ACE, struggle to work } \\
\text { with agencies }\end{array}$ & $\begin{array}{l}\text { No - not properly } \\
\text { managing the sand } \\
\text { erosion issue }\end{array}$ & $\begin{array}{l}\text { Not involved - instead Feds are a } \\
\text { "stumbling block", bureaocracy is } \\
\text { preventing env protection on the island }\end{array}$ \\
\hline $\mathrm{L}$ & $\begin{array}{l}\text { Sort of - mentioning changes in } \\
\text { demographics }\end{array}$ & N/A & $\begin{array}{l}\text { No - wrongly } \\
\text { managing deer }\end{array}$ & N/A \\
\hline$M$ & N/A & N/A & N/A & N/A \\
\hline $\mathrm{N}$ & $\begin{array}{l}\text { Yes; Some residents resent change } \\
\text { and don't like new residents being } \\
\text { involved }\end{array}$ & N/A & $\begin{array}{l}\text { Yes; agencies } \\
\text { involved (Dike, Port, } \\
\text { PUD); helpful with } \\
\text { problems on PI }\end{array}$ & $\begin{array}{l}\text { Aware of situations where agencies } \\
\text { reach out to community }\end{array}$ \\
\hline
\end{tabular}

\section{Activities}

\begin{tabular}{|c|c|c|c|c|c|c|c|}
\hline Interview & Fishing & Walking & Biking & $\begin{array}{l}\text { Community } \\
\text { Activities }\end{array}$ & Gardening/Farming & Boating & Parks/Marina \\
\hline \multicolumn{8}{|l|}{ A } \\
\hline B & & & & $x$ & & & \\
\hline C & & & & $x$ & $x$ & & \\
\hline D & $x$ & & & $x$ & $x$ & & \\
\hline$E$ & & & & & & $x$ & \\
\hline $\mathrm{F}$ & & & & & & $x$ & \\
\hline G & & & & $x$ & & & \\
\hline $\mathrm{H}$ & & & & $x$ & & & \\
\hline I & & $x$ & & No b/c snowbird & & & $x$ \\
\hline J & $x$ & $x$ & $x$ & $x$ & $x$ & $x$ & \\
\hline K & $x$ & $x$ & $x$ & & & & \\
\hline \multicolumn{8}{|l|}{$\mathrm{L}$} \\
\hline \multicolumn{8}{|l|}{ M } \\
\hline $\mathrm{N}$ & & & & & & & \\
\hline
\end{tabular}

\section{Description of PI Residents}

\begin{tabular}{|l|l|l|l|l|l|l|l|}
\hline Interview & Friendly & Talented & Old/New & Independent & Retirees & Family & Interdependent \\
\hline A & & & & & & & \\
\hline B & $x$ & & & & & & $x$ \\
\hline C & & $x$ & & $x$ & $x$ & & \\
\hline D & & $x$ & & $x$ & $x$ & & \\
\hline E & $x$ & $x$ & & & & & \\
\hline F & $x$ & $x$ & & & & & $x$ \\
\hline G & $x$ & & & & & $x$ & \\
\hline H & & & & & & & \\
\hline I & $x$ & & & & $x$ & & \\
\hline
\end{tabular}




\begin{tabular}{|l|l|l|l|l|l|l|l|}
\hline J & & & $x$ & & & & \\
\hline K & & & $x$ & & $x$ & & \\
\hline L & x & & & & & & \\
\hline M & & & & & $x$ & & \\
\hline N & $x$ & $x$ & $x$ & $x$ & & & \\
\hline
\end{tabular}

\section{Values}

\begin{tabular}{|c|c|c|c|c|c|c|c|c|c|c|}
\hline Interview & River & $\begin{array}{l}\text { Sereneness/ } \\
\text { Peace/Quiet }\end{array}$ & $\begin{array}{l}\text { Family } \\
\text { History }\end{array}$ & People & Safety & $\begin{array}{l}\text { Small Town/ } \\
\text { Rural }\end{array}$ & Proximity to cities & Fishing & Viewscape & Wildlife \\
\hline A & $x$ & $x$ & $x$ & $x$ & & & & & & \\
\hline B & & & & $x$ & & & & & & \\
\hline C & $x$ & & & $x$ & & $x$ & $x$ & & & \\
\hline D & $x$ & & & $x$ & & $x$ & $x$ & $x$ & & $x$ \\
\hline E & & & $x$ & $x$ & & & & & & \\
\hline $\mathrm{F}$ & $x$ & & & $x$ & & & & & & $x$ \\
\hline G & & & & $x$ & & & & & & \\
\hline $\mathrm{H}$ & & & $x$ & $x$ & & & & & & \\
\hline I & $x$ & $x$ & & & & $x$ & & & $x$ & \\
\hline J & & & & $x$ & $x$ & $x$ & $x$ & & $x$ & \\
\hline K & & $x$ & & & & & & & & \\
\hline $\mathrm{L}$ & $x$ & $x$ & & & & $x$ & & $x$ & & \\
\hline M & $x$ & & & & & & $x$ & & & \\
\hline $\mathrm{N}$ & & $x$ & & $x$ & $x$ & & & & & \\
\hline Total & 7 & 5 & 3 & 10 & 2 & 5 & 4 & 2 & 2 & 2 \\
\hline
\end{tabular}

\section{Environmental Issues}

\begin{tabular}{|c|c|c|c|c|c|c|c|c|c|c|c|}
\hline Interview & Deer & $\begin{array}{l}\text { Erosion/Beach } \\
\text { Protection }\end{array}$ & $\begin{array}{l}\text { Waste } \\
\text { (Recycling/Dumping) }\end{array}$ & $\begin{array}{l}\text { LNG } \\
\text { Plant }\end{array}$ & $\begin{array}{l}\text { Cattle } \\
\text { (Number, } \\
\text { care) }\end{array}$ & $\begin{array}{l}\text { Wetland } \\
\text { Protection } \\
\text { (Invasive } \\
\text { Species) }\end{array}$ & River & $\begin{array}{l}\text { Infrastructure } \\
\text { (Septic) }\end{array}$ & $\begin{array}{l}\text { Fish/Fishing } \\
\text { Industry }\end{array}$ & $\begin{array}{l}\text { Noise } \\
\text { Pollution }\end{array}$ & Pollution \\
\hline A & & $x$ & & & & $x$ & & & & & \\
\hline B & $x$ & & & & & & & & & & \\
\hline C & & & $x$ & $x$ & & & & & & & \\
\hline D & $x$ & & $x$ & $x$ & & $x$ & & & & & \\
\hline$E$ & & & & & & & & $x$ & & & \\
\hline $\mathrm{F}$ & & & & & & & & $x$ & & & $x$ \\
\hline G & $x$ & & & & & & & & & & \\
\hline $\mathrm{H}$ & $x$ & & & & & & & & & & \\
\hline I & & $x$ & & $x$ & $x$ & & & & $x$ & $x$ & \\
\hline J & & & & & & $x$ & $x$ & $x$ & & & \\
\hline K & $x$ & $x$ & & & $x$ & $x$ & & & & & \\
\hline L & $x$ & $x$ & $x$ & & & & & & & & \\
\hline$M$ & & & $x$ & & & & & & & & \\
\hline $\mathrm{N}$ & & & $x$ & $x$ & & & & & & & \\
\hline Total & 6 & 4 & 5 & 4 & 2 & 4 & 1 & 3 & 1 & 1 & 1 \\
\hline
\end{tabular}




\begin{tabular}{|c|c|c|c|c|c|c|}
\hline Interview & $\begin{array}{l}\text { Increased } \\
\text { Population }\end{array}$ & $\begin{array}{l}\text { Economic } \\
\text { changes }\end{array}$ & \begin{tabular}{|l|} 
More \\
retirees
\end{tabular} & None & $\begin{array}{l}\text { Beaches } \\
\text { (Sand pumping/ } \\
\text { erosion) }\end{array}$ & $\begin{array}{l}\text { Agricultural } \\
\text { Changes }\end{array}$ \\
\hline \multicolumn{7}{|l|}{$A$} \\
\hline B & $x$ & & $x$ & & & \\
\hline \multicolumn{7}{|l|}{$C$} \\
\hline \multicolumn{7}{|l|}{ D } \\
\hline$E$ & & $x$ & & & & $x$ \\
\hline $\mathrm{F}$ & & & & & & $x$ \\
\hline G & & & & & & $x$ \\
\hline $\mathrm{H}$ & & & & & & $x$ \\
\hline I & & $x$ & & & $x$ & \\
\hline J & $x$ & $x$ & & & & \\
\hline K & & $x$ & & & & \\
\hline $\mathrm{L}$ & & & & $x$ & & \\
\hline M & & $x$ & & & & \\
\hline $\mathrm{N}$ & $x$ & $x$ & $x$ & & & \\
\hline Total & 3 & 6 & 2 & 1 & 1 & 4 \\
\hline
\end{tabular}

